\title{
Anatomy of Petal Drop in Sunflowers
}

\author{
Joyous Suiyigheh Tata ${ }^{1}$ and Hans Christian Wien \\ Department of Horticulture, Cornell University, 134A Plant Science Building, Ithaca, NY 14853
}

\begin{abstract}
ADDITIONAL INDEX wORDs. petal abscission, break strength, detachment force, abscission zone, separation layer, petal-achene juncture

Abstract. The petals of some sunflower (Helianthus annuus) cultivars used as cut flowers are easily knocked off the flower; this ruins its appearance and destroys its market value. The objectives of this study were to characterize an abscission zone, if present, at the base of petals of sunflower florets in cultivars that differ with respect to petal drop and to determine if differences in the nature and/or development of the abscission zone among cultivars were correlated with differences in timing with respect to petal drop. In the first experiment, we measured the force required to pull petals from the flower head; in the second we investigated changes in the anatomy of the petal-achene juncture. Anatomical analysis revealed a differentiated region (the abscission zone) at the junction of the petal and achene consisting of cells with a different morphology from those above and below it. Cell division at the abscission zone of the short-lived cultivar occurred earlier than in the long-lived cultivar. These differences indicate that whereas the anatomical nature of the abscission zone is similar in the two cultivars, Procut Yellow Lite (PYL) and Procut Bicolor (PBC), the tempo of development differed. Specifically, the abscission layer reached full differentiation, or maturity, sooner in PBC, hence its earlier petal drop, than in PYL.
\end{abstract}

Ornamental sunflowers have become increasingly popular as cut flowers the world over (Blacquière et al., 2002; Devecchi, 2005). Despite its popularity as a cut flower, growers of cut sunflowers have long complained about the susceptibility of some cultivars to loss of petals soon after the flowers open. This ruins the appearance of the flowers and destroys their market value. This can happen within a day of the flowers' opening and the petals flattening out. There has been no systematic study of this problem in literature, although sunflower growers have been actively selecting for cultivars that are less prone to this condition. Many researchers (Evensen et al., 1993a; Fernandez et al., 2000; Lease et al., 2006; McKenzie and Lovell, 1992; Patterson and Bleecker, 2004) have used physical methods such as measurement of break strength to study petal abscission. Break strength is a quantitative measure of the force required to detach an organ from the body of a plant. Past studies on the anatomy of petal drop in other species reveal that the process involves the separation of four to five rows of smaller transversely oriented cells that laid horizontally across the diameter at the juncture between the petal and the achene (Sexton, 1994; Sexton et al., 2000; Sexton and Roberts, 1982). Separation in tulip (Tulipa hybrid cv. Golden Apeldoorn and Tulipa kaufmanniana cv. Shakespeare) tepal abscission happens along a fractured line (Sexton et al., 2000).

The objectives of this study were to define and characterize an abscission zone, if present, at the base of petals of sunflower florets in cultivars that differ with respect to petal drop and to determine if differences in the nature and/or development of the abscission zone among cultivars were correlated with differences in timing with respect to petal drop. The hypotheses were that 1) a specific set of anatomical and microchemical details that might enhance the tendency of sunflowers to drop their

Received for publication 18 Mar. 2014. Accepted for publication 16 Sept. 2014. This paper is a portion of a thesis submitted by Joyous Suiyigheh Tata in partial fulfillment of the requirements for the degree of Doctor of Philosophy at Cornell University.

We thank Dominick Paolillo immensely for allowing us to use his laboratory for this work.

${ }^{1}$ Corresponding author. E-mail: sjtata@illinois.edu. petals can be used to characterize an abscission zone; and 2) the anatomical details that characterize the abscission zone will differ among cultivars in a way that correlates with differences in tendency to drop petals.

\section{Materials and Methods}

Two sunflower cultivars: Procut Bicolor, a cultivar that loses its petals easily (short-lived), and Procut Yellow Lite, a cultivar that holds unto its petals much longer (long-lived), were selected for this study. The two sunflower cultivars used in this study are pollen-free hybrids developed by Johnny's Selected Seeds (Waterville, ME).

In the first experiment, separation force measurements were taken for the two sunflower cultivars using a modification of a soil cone micropenetrometer apparatus that measures separation forces in the opposite direction. The petal detachment force technique was adapted from a method described by Moebius-Clune et al. (2008) for intact soil core penetration resistance measurement in the laboratory. This device $(1000 \mathrm{~kg}$ arbor press, SKU 3552; Central Machinery, TAL Technologies, Philadelphia, PA) consists of a scale that is connected to a computer. The flower was held down on the scale by a weight of $2 \mathrm{~kg}$. An alligator clip inserted into the drill press chuck was attached to a random petal. The scale was tared to zero (Fig. 1). The drill press lever was slowly raised (at $\approx 0.005 \mathrm{~m} \cdot \mathrm{s}^{-1}$ ) and the force by which the weight on the scale diminishes was recorded on the computer each second. The highest negative recorded value before breakage was used to represent the "break strength." This value represents the force needed to detach that petal from the receptacle of the flower. The force that was required to remove the petals from inflorescence of PBC and PYL was sampled over a 12-d period after anthesis. Flowers were harvested at first anthesis, put in glass vases with distilled water, and stored at a room temperature of $20{ }^{\circ} \mathrm{C}, 60 \%$ relative humidity (RH), and $12 \mathrm{~h} \cdot \mathrm{d}^{-1}$ fluorescent lighting. Force readings for both cultivars were taken on Days 1, 3, 6, 9, and 12 after harvest. A minimum of four petals was pulled on each inflorescence and the readings were averaged. Ten single inflorescence replicates per cultivar 


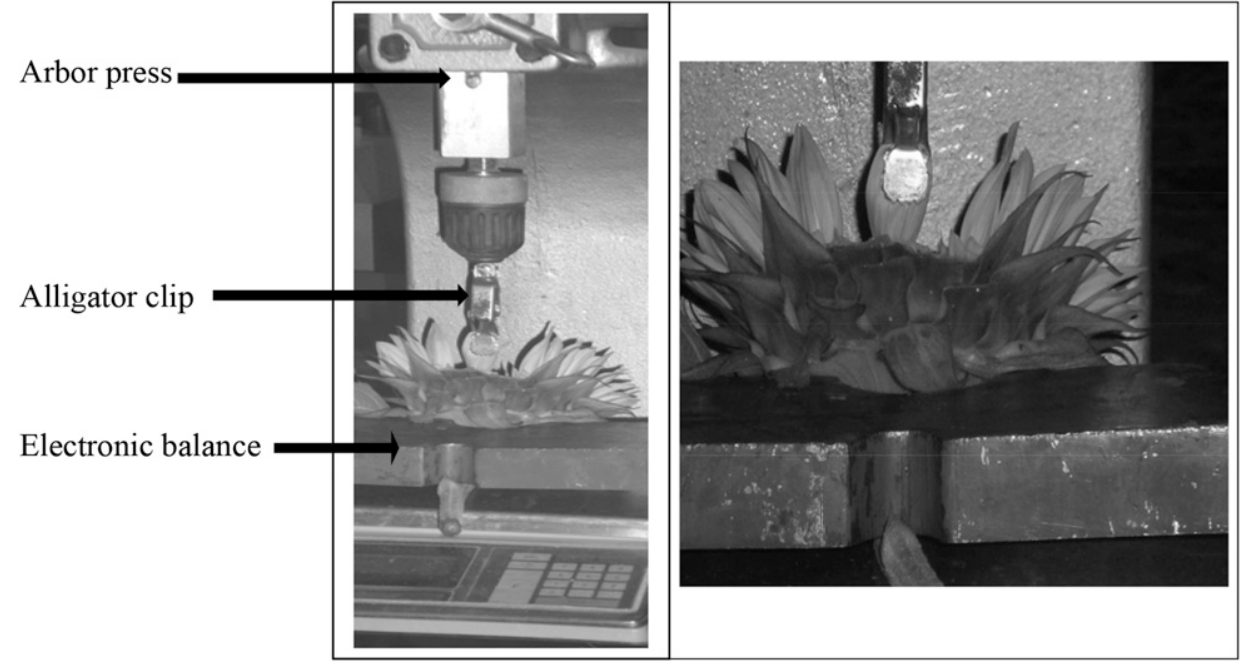

Fig. 1. The petal break strength meter (built specifically for this study): pulling on the petal while the sunflower is pinned to an electronic scale by a $2-\mathrm{kg}$ weight. The alligator clip attached to a random petal is pulled slowly upward. The scale that is connected to a computer measures the force reduction on the load cell as the petal is being pulled and the reading recorded directly into an Excel spreadsheet (Microsoft Corp., Redmond, WA).

relevance; when the flower just opens (anthesis), $8 \mathrm{~d}$ (the end of flower life for PBC), and $12 \mathrm{~d}$ (the end of flower life for PYL). We added an arbitrary time point (4 $\mathrm{d}$ after harvest), when the anatomy of petals of the two cultivars was also studied. The end of flower life was defined as the time (in days) when detachment force equals zero; a gentle touch of petals with the index finger causes them to fall off easily. Flowers were harvested at first anthesis, put in glass vases with distilled water, and stored at a room temperature of $20^{\circ} \mathrm{C}, 60 \% \mathrm{RH}$, and $12 \mathrm{~h} \cdot \mathrm{d}^{-1}$ fluorescent lighting. The vases were washed and sterilized, and deionized water was changed daily to avoid bacterial contamination. Ray florets were fixed in formalin-aceto-acid for at least $72 \mathrm{~h}$ and then dehydrated through ethanol and butanol series described by Johansen

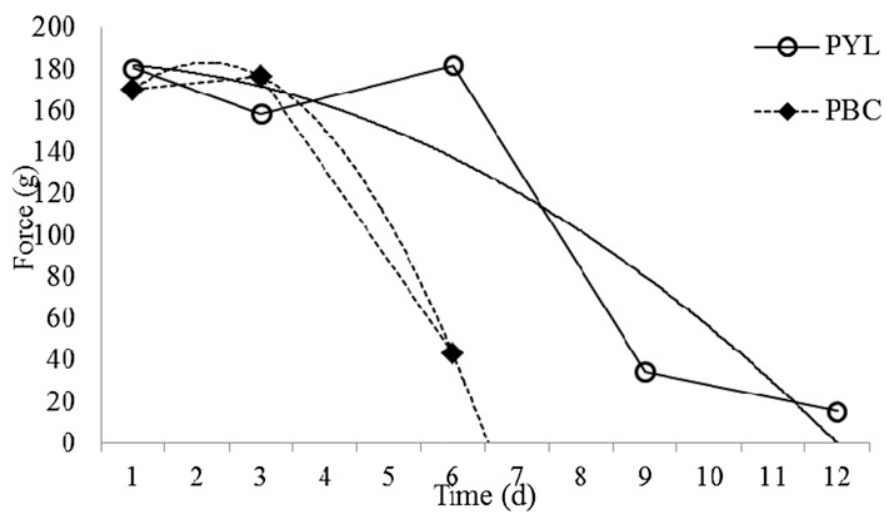

Fig. 2. The break strength or force required to remove petals from the receptacle of short-lived sunflower cultivar Procut Bicolor (PBC) vs. long-lived cultivar Procut Yellow Lite (PYL) measured on Days 1, 3, 6, 9, and 12 after harvest. The graph shows the cultivar and regression plots for each cultivar. Regression formula for $\mathrm{PBC}$ : force $=138.32+41.15$ time $($ days $)-9.5$ time $^{2}$ (days). Regression formula for PYL: force $=175.60+6.25$ time $($ days $)-$ 1.75 time $^{2}$ (days).

were pulled on Days 1, 3, 6, 9, and 12 after harvest. Results were analyzed using analysis of variance and GLM regression procedures on JMP 10 statistics (SAS Institute, Cary, NC). To develop a regression equation that could predict vase life, break strength measurements were obtained for 13 sunflower cultivars on Days 1, 3, 6, 9, and 12 after harvest. Flowers of the 13 cultivars were harvested at first anthesis, put in glass vases with distilled water, and stored at a room temperature of $20{ }^{\circ} \mathrm{C}, 60 \% \mathrm{RH}$, and $12 \mathrm{~h} \cdot \mathrm{d}^{-1}$ fluorescent lighting. Force readings for the 13 cultivars were taken on Days 1, 3, 6, 9, and 12 after harvest. A minimum of four petals was pulled on each inflorescence and the readings were averaged. Ten single inflorescence replicates per cultivar were pulled on Days 1, 3, 6, 9, and 12 after harvest.

In the second experiment, we studied the changes in the anatomy of the petal-achene juncture of the two cultivars. Three stages from PBC and four stages from PYL were studied. These stages represent a time course with physiological
(1940). For dehydration, the following normal butyl alcohol series were used: $70 \%, 85 \%, 95 \%$, and $100 \%$. The last two changes were made with pure normal butyl alcohol. Paraffin sections $(\approx 10 \mu \mathrm{m})$ at the stages described previously for both cultivars were stained with toluidine blue $\mathrm{O}$ and examined by light microscopy. Tests for suberin, lignin, and pectic substances were done using thin hand sections. Three florets each from two inflorescences in each stage were studied. Three sections from each floret were studied. These experiments were repeated three times.

Staining protocols used for microchemical tests for suberin, lignin, and pectic substances were from Johansen (1940), and a test for general cell morphology was done using methods described by Ruzin (1999). To test for suberin, a saturated solution of Sudan IV in $70 \%$ alcohol was used. For lignin, sections were placed on a slide in a large drop of solution of $0.1 \mathrm{~g}$ phloroglucin in $10 \mathrm{~mL}$ of $95 \%$ alcohol and covered with a coverslip. Part of the solution was allowed to evaporate, and a little $25 \%$ hydrochloric acid was allowed to diffuse in at the edge of the coverslip. To test for pectic substances, ruthenium red dye was used. For general cell morphology, $0.05 \%$ in $50 \mathrm{~mm}$ citrate buffer, $\mathrm{pH}$ less than 5 , was used.

\section{Results and Discussion}

The results from the two experiments used in this study point in the same direction.

\section{Detachment force analysis}

Results from the physical study (Fig. 2) show that PYL had a high detachment force on Day 1 (180.58 g), Day 3 (158.74 g), and Day 6 (181.76 g). However, detachment force decreased on Day 9 (34.52 g) and Day 12 (15.39 g). Cultivar PBC had a high detachment force on Day 1 (170.29 g) and Day 3 (176.41 g). However, on Day 6, detachment force decreased significantly to $42.83 \mathrm{~g}$ compared with that of PYL (181.76 g) on the same day. Although detachment forces switched from high to low in both cultivars, that of the short-lived cultivar occurred earlier 
(on Day 6 at $42.83 \mathrm{~g}$ ) than the long-lived cultivar (Day 9 at $34.52 \mathrm{~g})$. These results reveal that there was a difference in timing in the formation and maturation of the separation layer between the two cultivars. Detachment forces switched from an initial high to low in both cultivars because of the maturation of the separation layer. This maturation occurred earlier in the cultivar that is first to lose its petals (PBC). There were no force readings for the short-lived cultivar on Day 9 and Day 12 because the flower had wilted by Day 9 .

REgRession aNALYSES ON PETAL BREAK STRENGTH DATA. The results of the data analyses presented below were carried out using JMP 10 statistical software. The data were obtained from break strength experiments carried out on 13 sunflower cultivars as described previously. The aim was to develop a regression equation that could predict vase life of a sunflower cultivar using physical characteristics of color and petal break strength. In the analysis, the innate physical characteristic of color was used to distinguish the different sunflower cultivars rather than their cultivar names. It was felt that the cultivar name was an extrinsic characteristic and therefore not a suitable independent proxy for the physical characteristics of the sunflower species. Color being an independent physical characteristic of sunflowers permits an aggregation of the 13 sunflower cultivars used in this study into major color groups shown in Table 1. The regression analysis of break strength data shown below is grouped by sunflower color and vase life.

Results of regression analysis on break strength data grouped by color. Table 2 shows that the mean break strength of cultivars in the yellow group were higher and significantly different (at $P<0.05$ ) from cultivars in the orange and bicolor groups, which were in turn higher and significantly different from cultivars in the red group. Table 5 shows that the mean vase life $(12 \mathrm{~d})$ of the sunflower cultivars in the yellow group was longer than cultivars in the orange group $(10 \mathrm{~d})$, which in turn were longer than cultivars in the bicolor group ( $9 d)$, which in turn were higher and significantly different from cultivars in the red group $(8 \mathrm{~d})$. The orange and bicolor groups did not

Table 1. Color category and coding of 13 sunflower cultivars.

\begin{tabular}{ll}
\hline Cultivar & Color category \\
\hline Chianti & Red group \\
Cherry Rose & Red group \\
Moulin Rouge & Red group \\
Procut Bicolor & Bicolor group \\
Procut Red Lemon Bicolor & Bicolor group \\
Strawberry Blonde & Bicolor group \\
Orange Glory & Orange group \\
Procut Early Orange & Orange group \\
Procut Orange & Orange group \\
Procut Peach & Orange group \\
Sunrich Orange & Orange group \\
Procut Lemon & Yellow group \\
Procut Yellow Lite & Yellow group \\
\hline
\end{tabular}

differ. Thus, vase life has a strong relationship with flower color with the darker cultivars in this study having a shorter vase life compared with the lighter cultivars.

REGRESSION OF BREAK STRENGTH BY VASE LIFE DATA GROUPED BY TIME AFTER HARVEST. Based on the parameter estimates and the quadratic prediction model, the regression equation for predicting vase life of the sunflower cultivars in this study from break strength values obtained 1 and $6 \mathrm{~d}$ after harvest are:

$$
\begin{gathered}
\text { Force }_{(\text {dayl })}=126.83-5.38(\text { vase life })+0.85(\text { vase life })^{2} \\
\text { Force }_{(\text {day })}=29.03-9.17\left(\text { vase life }^{2}\right)+1.6\left(\text { vase life }^{2}\right.
\end{gathered}
$$

Table 3 shows the observed and predicted vase life of 13 sunflower cultivars computed using regression Eq. [1] and Eq. [2]. In Table 4, the correlation between observed vase life and predicted vase life using Eq. [1] is 0.616 and this is significant; the correlation between observed vase life and predicted vase life using Eq. [2] is 0.717 and this is also significant; this implies that Eq. [2] is a better predictor of vase life when break strength data are known.

\section{Anatomical analysis}

To understand the anatomical changes taking place at the petal-achene juncture, we examined sections from both cultivars stained with toluidine blue $\mathrm{O}$. Three stages from the shortlived and four stages from the long-lived cultivar were studied as described previously. Results showed a differentiated region at the junction of the petal and achene consisting of cells with a different morphology from those above and below. In the final stages of development in both cultivars (Fig. 3A-B), the cells at this region were oval to elliptical in shape as seen in sections parallel to the axis of the achene and petal with their long dimensions transverse to that axis. The more distal cells (technically in the petal) were elongated in the direction of the axis of the petal. The proximal cells (those in the achene) were polygonal and more or less isodiametric. Those proximal to the region were more closely packed compared with the distal cells. Because the petals separate from the achenes by the destruction of cells within the region of transversely oriented cells (the separation layer), it is permissible to refer to the region as an abscission zone (Sexton, 1994; Sexton et al., 1985; Sexton and Roberts, 1982).

The abscission zone as seen in the final stages of development in both cultivars (Fig. 3A-B) had between four and five layers of smaller transversely oriented cells that laid horizontally across the diameter at the junction between the petal and the achene, where the separation takes place. The separation layer was uninterrupted and traversed the entire plane of the abscission zone. Apart from the separation layer cells (those found in the newly differentiated region where separation eventually occurs), the separation layer also consisted of cells that were destined to be part of the surface of the achene after it is free of the petal. These cells were different

Table 2. Relationship among flower color and petal break strength (g) for 13 sunflower cultivars.

\begin{tabular}{lccc}
\hline & \multicolumn{3}{c}{ Color category } \\
\cline { 2 - 4 } Least square means & Yellow $(\mathrm{n}=420)$ & Orange $(\mathrm{n}=576)$ & Bicolor $(\mathrm{n}=439)$ \\
\cline { 2 - 4 }
\end{tabular}

${ }^{\mathrm{z}}$ Means followed by the same letter are not significantly different at $P<0.05$ by Tukey's honest significant difference adjustment test. 
Table 3. Observed and predicted vase life for 13 sunflower cultivars computed using regression equation. ${ }^{\mathrm{z}}$

\begin{tabular}{|c|c|c|c|c|c|}
\hline Cultivar & $\begin{array}{l}\text { Avg force } \\
\text { at Day } 1(\mathrm{~g})\end{array}$ & $\begin{array}{l}\text { Avg force } \\
\text { at Day } 6(\mathrm{~g})\end{array}$ & $\begin{array}{c}\text { Observed } \\
\text { vase life }(\mathrm{d})\end{array}$ & $\begin{array}{c}\text { Predicted vase } \\
\text { life based on force at } \\
\text { Day } 1(\mathrm{~d})\end{array}$ & $\begin{array}{l}\text { Predicted vase life based } \\
\text { on force at Day } 6(\mathrm{~d})\end{array}$ \\
\hline Chianti & 108.09 & 29.57 & 9 & 7 & 6 \\
\hline Moulin Rouge & 130.52 & 95.85 & 9 & 7 & 10 \\
\hline Orange Glory & 168.25 & 12.24 & 9 & 11 & 4 \\
\hline Procut Bicolor & 170.29 & 42.83 & 6 & 11 & 7 \\
\hline Procut Lemon & 215.16 & 169.27 & 12 & 14 & 13 \\
\hline Procut Orange & 202.92 & 92.79 & 9 & 13 & 10 \\
\hline Procut Peach & 124.41 & 28.55 & 6 & 6 & 6 \\
\hline Procut Red Lemon Bicolor & 204.96 & 134.60 & 9 & 13 & 12 \\
\hline Procut Yellow Lite & 181.51 & 170.29 & 12 & 12 & 13 \\
\hline Strawberry Blonde & 134.60 & 95.85 & 9 & 8 & 10 \\
\hline
\end{tabular}

${ }^{\mathrm{z}}$ Regression formulas for 13 sunflower cultivars are as follows where time is in days: Procut Bicolor (force $=138.32+41.15$ time -9.5 time ${ }^{2}$ ), Procut Yellow Lite $\left(\right.$ force $=175.60+6.25$ time -1.75 time $\left.^{2}\right)$, Chianti $\left(\right.$ force $=133.61-11.37$ time -0.51 time $\left.{ }^{2}\right)$, Sunrich Orange $($ force $=180.31-$ 14.06 time -0.01 time $\left.^{2}\right)$, Cherry Rose $\left(\right.$ force $=117.35+12.57$ time -4.45 time $\left.^{2}\right)$, Moulin Rouge $\left(\right.$ force $=128.04+7.08$ time -1.89 time $\left.{ }^{2}\right)$, Orange Glory $\left(\right.$ force $=220.36-40.51$ time $\left.+1.68 \mathrm{Time}^{2}\right)$, Procut Early Orange $\left(\right.$ force $=203.20-14.02$ time -0.29 time $\left.{ }^{2}\right)$, Procut Lemon $($ force $=208.50$ 4.71 time -1.06 time $\left.^{2}\right)$, Procut Orange $\left(\right.$ force $=227.20+28.39$ time +0.93 time $^{2}$ ), Procut Peach $\left(\right.$ force $=109.97+20.53$ time -5.68 time $\left.{ }^{2}\right)$, Strawberry Blonde $\left(\right.$ force $=135.16+1.02$ time -1.57 time $^{2}$ ), Procut Red Lemon Bicolor $\left(\right.$ force $=202.21-3.17$ time -1.75 time ${ }^{2}$ )

Table 4. Correlation between observed and predicted vase life (d) of 13 sunflower cultivars based on values in Table 3.

\begin{tabular}{|c|c|c|c|c|}
\hline & & Observed vase life ${ }^{\mathrm{z}}$ & Predicted vase life $1^{\mathrm{y}}$ & Predicted vase life $2^{x}$ \\
\hline \multirow[t]{3}{*}{ Observed vase life } & Pearson correlation & 1 & $0.616^{*}$ & $0.717 * *$ \\
\hline & Significance (two-tailed) ${ }^{\mathrm{w}}$ & & 0.025 & 0.006 \\
\hline & Number & 13 & 13 & 13 \\
\hline & Significance (two-tailed) & 0.025 & & 0.028 \\
\hline & Number & 13 & 13 & 13 \\
\hline \multirow[t]{2}{*}{ Predicted vase life 2 (using Eq. [2]) } & Pearson correlation & $0.717 * *$ & $0.608^{*}$ & 1 \\
\hline & Number & 13 & 13 & 13 \\
\hline
\end{tabular}

${ }^{\mathrm{z}}$ Time after harvest at which all the petals have completely fallen off.

${ }^{y}$ Values for vase life based on vase life regression equation: Force (Day 1) $=126.83-5.38$ (vase life) $+0.85\left(\right.$ vase life) ${ }^{2}$. The values for predicted vase life 1 are shown in Table 3.

${ }^{x}$ Values for vase life based on vase life regression equation: Force (Day 6) $=29.03-9.17$ (vase life) $+1.6\left(\right.$ vase life) ${ }^{2}$. The values for predicted vase life 2 are shown in Table 3.

wStatistical significance at 0.05 or 0.01 level.

*, ** Correlation significant at the 0.05 level (two-tailed) and 0.01 level (two-tailed), respectively.

Table 5. Relationship among flower color and vase life (d) for 13 sunflower cultivars.

\begin{tabular}{lcccc}
\hline & \multicolumn{3}{c}{ Color category } \\
\cline { 2 - 4 } Least square means & $12.0 \mathrm{a}^{\mathrm{z}}$ & Orange $(\mathrm{n}=576)$ & Bicolor $(\mathrm{n}=439)$ & Red $(\mathrm{n}=621)$ \\
\cline { 2 - 4 } & $9.93 \mathrm{~b}$ & $9.0 \mathrm{~b}$ & $8.13 \mathrm{c}$ \\
\hline
\end{tabular}

${ }^{\mathrm{z}}$ Means followed by the same letter are not significantly different at $P<0.05$ by Tukey's honest significant difference adjustment test.

from the separation zone cells in that they were polygonal and more or less isodiametric (Fig. 3A-B). The cells at the separation layer in both cultivars were relatively cytoplasmic with intact organelles, plastids containing small starch grains, and no visible intercellular spaces (Fig. 3A-B). Results from tests for the presence of lignin, suberin, and pectic substances revealed that there was no accumulation of these substances in the abscission zones of sunflowers.

The separation layer was seen to change over time from Stage 1 to Stage 3 in PBC and from Stages 1 through 4 in PYL. In Stage 1 (Fig. 4A-B), the cells at the separation layer were tightly packed and more or less undifferentiated across both cultivars. At Stage 3 for PBC (Fig. 4E), the cells in the separation layer were seen to be more defined, expanded, and rounded. It is assumed that PBC (the short-lived cultivar) attains maximum cell differentiation at this stage. Results from petal detachment force confirm that by Stage 3 (Day 8 ) the force of attachment was zero (Fig. 2) as a result of the formation and maturation of the separation layer, which causes the petals to drop by a gentle touch at this time. The long-lived cultivar continued to hold its petals until Day 12 (Fig. 2). At Stage 4 (Day 12), the cells at the separation layer of the long-lived 


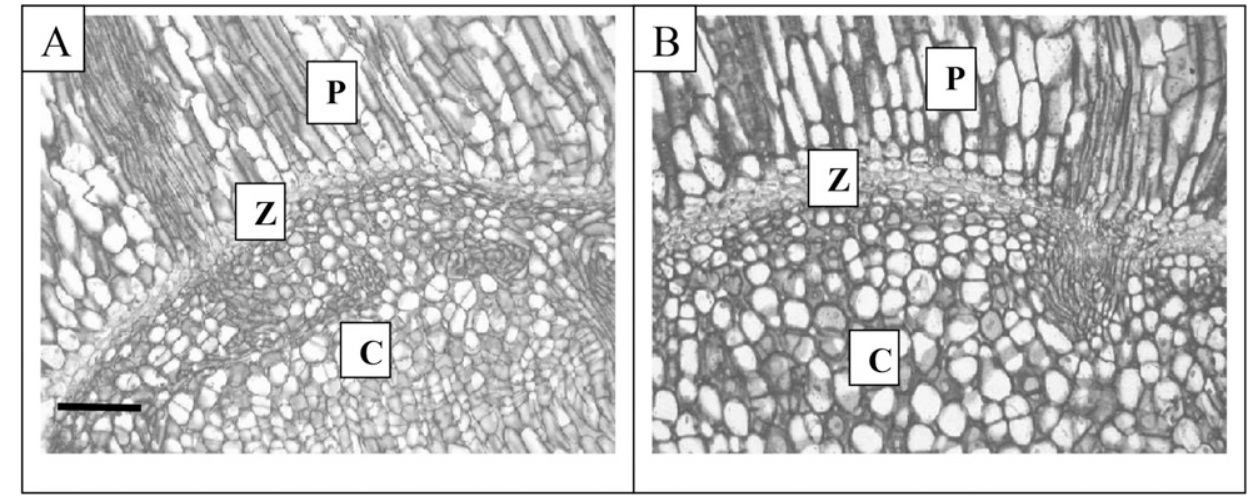

Fig. 3. Longitudinal light micrograph (LM) sections through the petal base of a short-lived sunflower cultivar Procut Bicolor (A) on Day 8 and a long-lived cultivar Procut Yellow Lite (B) on Day 12; P = petal; $\mathrm{C}=$ achene consisting of isodiametric cells; $\mathrm{Z}=$ location of the abscission zone in both cultivars; $120 \times$, bar $=100 \mu \mathrm{m}$
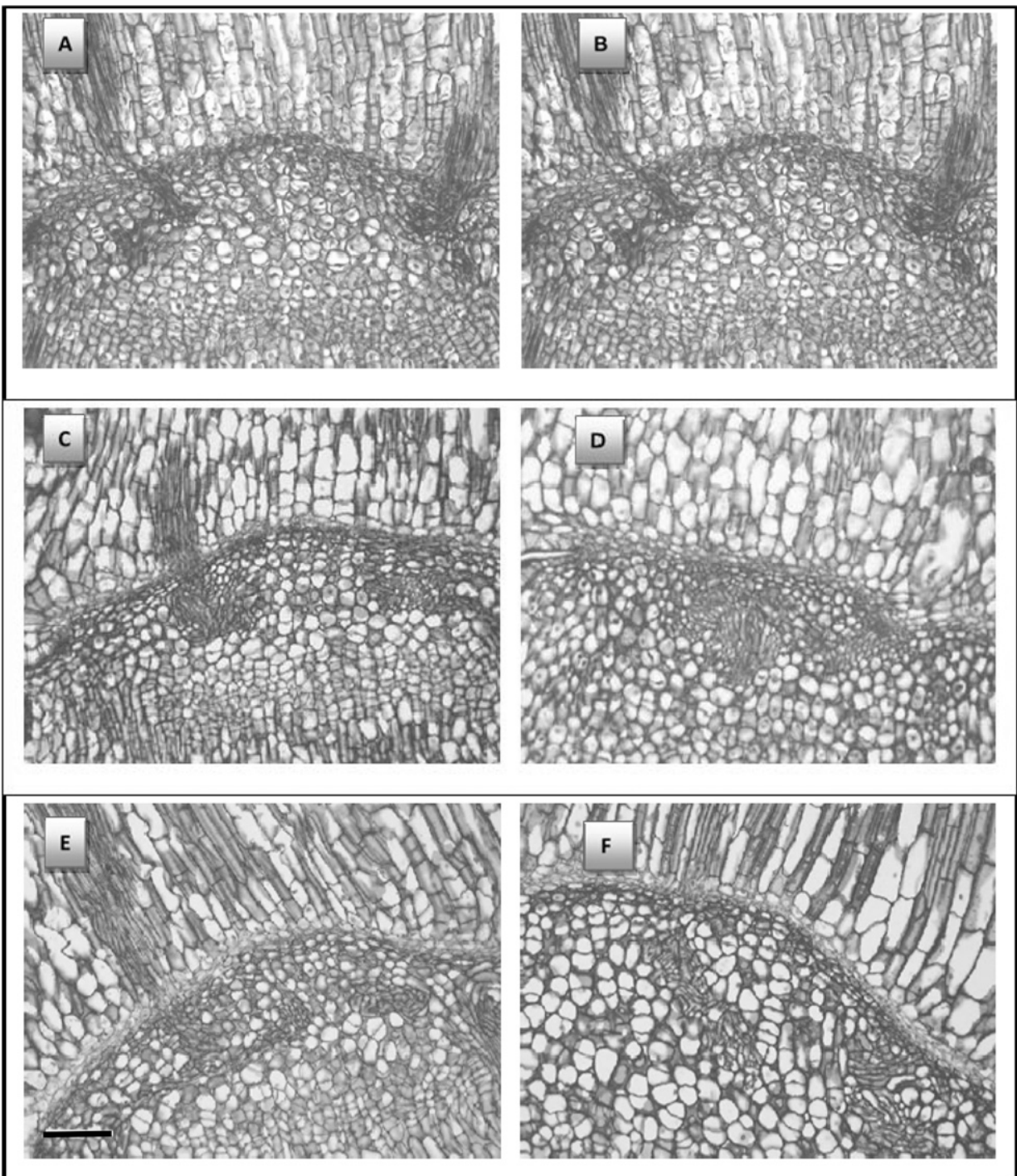

Fig. 4. The change in the appearance of the separation layer over time for short-lived sunflower cultivar Procut Bicolor (A) and long-lived cultivar Procut Yellow Lite (B) at Stage 1 (Day 1); for 'Procut Bicolor' (C) and 'Procut Yellow Lite' (D) at Stage 2 (Day 4); and for 'Procut Bicolor' (E) and 'Procut Yellow Lite' (F) at Stage 3 (Day 8); 120×, bar $=100 \mu \mathrm{m}$. cultivar (Fig. 7) in turn expand and became rounded. Petal detachment force measurements confirmed that by Stage 4 (Day 12), the detachment forces decreased significantly [15.39 g (Fig. 2)].

Although the separation layer of PYL was only two layers thick on Day 8, that of PBC was four layers on Day 8 when it drops its petals. Cultivar PYL dropped its petals $4 \mathrm{~d}$ later (Day 12) with a five-layerthick separation layer. This result reveals that cell division at the abscission zone of the short-lived cultivar occurred earlier and faster than that in the long-lived cultivar. These differences indicate that whereas the anatomical and cellular nature of the abscission zone is similar in the two cultivars, the tempo of development differs in a way that seems to account for earlier petal drop in cultivar PBC. Specifically, the abscission layer reaches full differentiation, or maturity, sooner in PBC than in PYL. Results from petal detachment force analysis confirm the evidence presented here. These results further reveal the horticultural importance of abscission in petal drop of sunflowers in general and that the differences in timing of the formation and maturation of an abscission zone account for the differences in timing to petal drop in sunflower cultivars that differ with respect to petal drop.

In Figure 4A and B, note that at Stage 1 , the cells are tightly glued together and no separation layer is apparent. By Stage 3 (Fig. 4E-F), the weakening process appears faster in PBC than PYL and petal drop happened for this cultivar at this time, whereas PYL continues to hold its petals until Stage 4 .

Figures 5 and 6 are higher magnification pictures taken on Day 8 for PBC and PYL, respectively. Figure 5 shows that the speed of development and maturation of the separation layer were faster in the short-lived cultivar PBC than in the long-lived cultivar (Fig. 6) on the same day. This can be seen by the number of cell layers at the separation zone in both cultivars (indicated by the arrows). The short-lived cultivar had four cell layers (Fig. 5) at the separation zone on Day 8, whereas the 


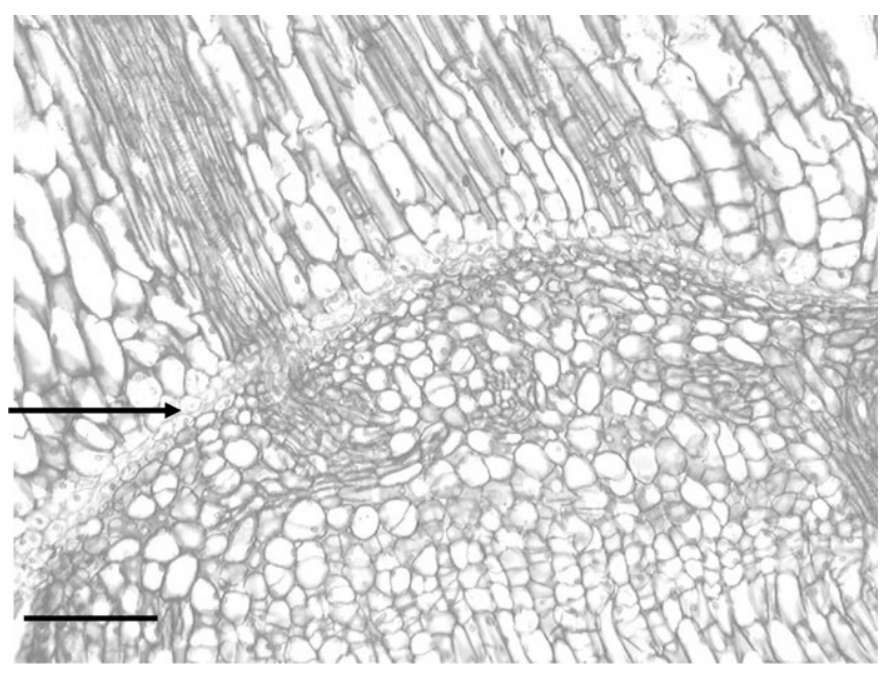

Fig. 5. A high-magnification picture of the short-lived sunflower cultivar Procut Bicolor taken on Day 8 showing a fully differentiated and mature separation layer (see arrow); $220 \times$, bar $=100 \mu \mathrm{m}$.

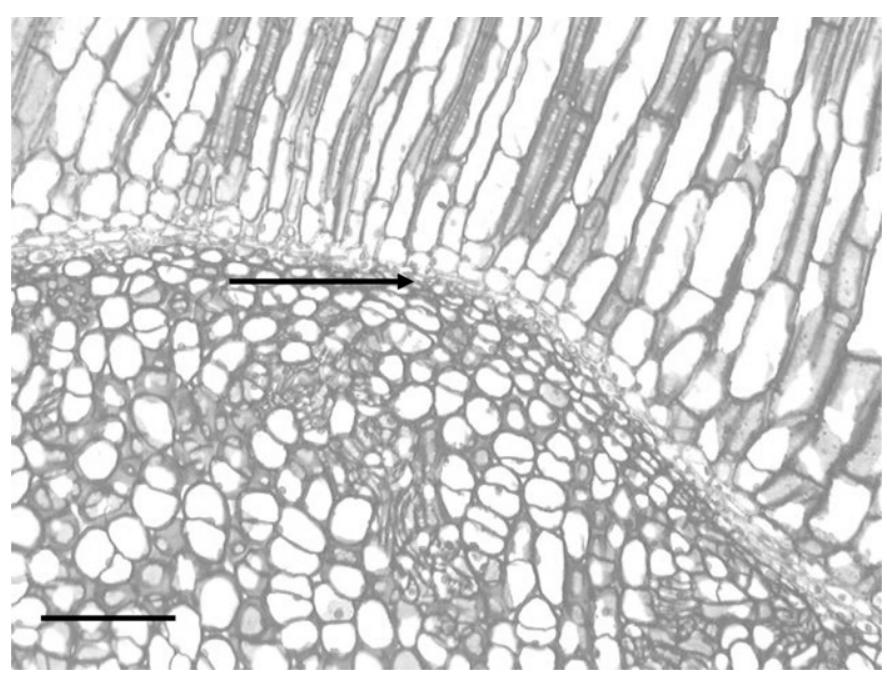

Fig. 6. A high-magnification picture of the long-lived sunflower cultivar Procut Yellow Lite taken on Day 8 showing the progression of cell differentiation at the separation layer (see arrow). The separation layer is less developed in 'Procut Yellow Lite' on Day 8 compared with PBC. $220 \times$, bar $=100 \mu \mathrm{m}$.

long-lived cultivar had only two (Fig. 6). Petal drop happened for PBC on Day 8, whereas PYL continued to hold its petals until Day 12 (Fig. 7). The separation layer of PYL had five cell layers on Day 12 (Fig. 7). These results reveal that the separation layer differentiates and matures faster in PBC than in PYL, which causes PBC to drop its petals earlier than PYL.

There were recognizable tracheary elements from the achene up through the separation layer into the petal in all treatments in both cultivars. However, the tracheary elements seemed to stop when they reached the abscission zone by Days 8 and 12 when the separation layer was fully differentiated and mature in PBC and PYL, respectively (Fig. 3A-B). The separation layer in both cultivars was continuous and uninterrupted.

The anatomy of petal drop in sunflower is similar to the majority of established descriptions in other species (Sexton,

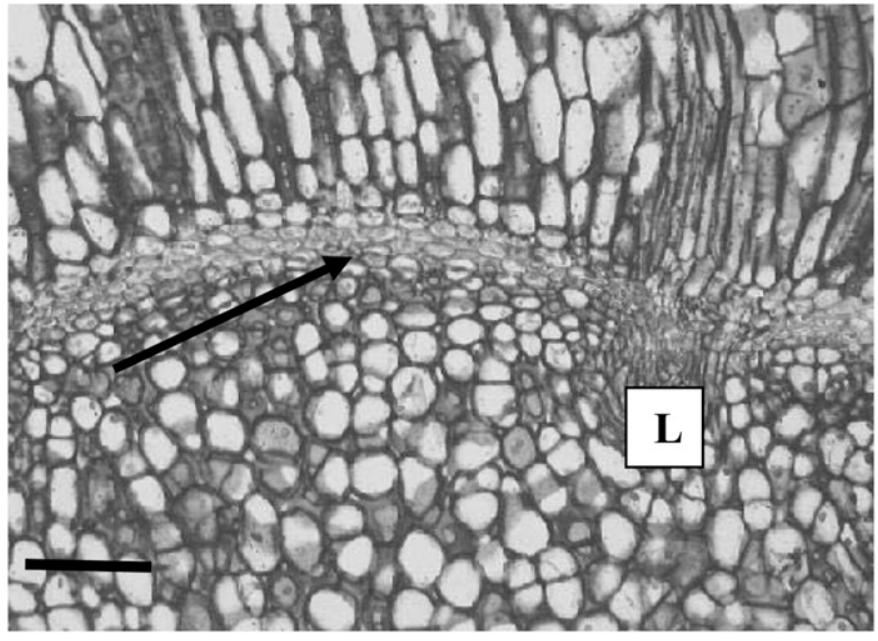

Fig. 7. Light micrograph showing a mature separation layer (see arrow) for long-lived sunflower cultivar Procut Yellow Lite at Stage 4 (Day 12) when the cultivar drops its petals; by this time, flowers of short-lived cultivar Procut Bicolor has lost their petals. L shows tracheary elements. Tracheary elements appear less well developed during the separation process; $120 \times$, bar $=100 \mu \mathrm{m}$.

1994; Sexton et al., 1985; Sexton and Roberts, 1982exton et al., 2000). The process involved the separation of four to five rows of smaller transversely oriented cells that laid horizontally across the diameter at the juncture between the petal and the achene, the separation layer. Although separation in tulip tepal abscission happens along a fracture cultivar (Sexton et al., 2000 ), in sunflower it happens in a separation layer.

The separation layer in sunflower was produced by cell division before the separation process happens. The separation layer was uninterrupted and traversed the entire plane of the abscission zone. The cells at the separation layer were smaller and oval to elliptical in shape and morphologically distinct from those distal and proximal to that region. The petal separated from the achene by the destruction of cells at the separation layer. The process of cellular separation has been proposed to be restricted to one to five layers of cells, the "separation layer," which is found in a flat uninterrupted plane that cuts across the whole structure (Gawadi and Avery, 1950; Hodgson, 1918). The separation zone cells in sunflower appear to remain intact, expanded, and rounded during the separation process. Sexton and Redshaw (1981) reported for Impatiens sultani that cells at the separation layer expand and become rounded during abscission. The separation layer cells in sunflower were also relatively cytoplasmic with intact organelles and plastids. These results are similar to the separation process in tulip tepal abscission (Sexton et al., 2000).

Although cell separation in tulip tepal abscission and many other species results from the breakdown of the middle lamella and adjacent areas of the primary wall (Polito and Lavee, 1980; Sexton et al., 2000; Webster, 1973), in sunflower, there is no visible breakdown of the middle lamella and the cells at the separation layer appear to have contact with other surrounding cells during separation. In Pelargonium Xhortorum (Evensen et al., 1993b), the middle lamella was extensively degraded with some cells in the abscission zone appearing to have no contact with most of the surrounding cells. This was not the case in sunflower. In tulip, the separation process appeared to start at the periphery of the tepal base and spread centripetally, 
but in sunflowers, there appeared to be no specific location where the separation began.

There was a difference in timing in the formation and maturation of the separation layer between the two cultivars, which accounts for the difference in timing to petal drop in sunflower cultivars that differ with respect to petal drop. Although the anatomical and cellular nature of the abscission zone is similar in the two cultivars, the tempo of development differs in a way that seems to account for earlier petal drop in PBC compared with PYL. The development and maturation of the separation layer was faster in PBC compared with PYL.

There was no accumulation of lignin, suberin, or pectic substances in the separation layer. This has been confirmed in abscission processes of other species. Failure to lignify is a characteristic of the separation layer (Facey, 1950). Osborne (1989) suggested that pectins are degraded and their bonds with other molecules cleaved by hydrolytic enzymes.

\section{Conclusion}

The concept that the timing of the maturation of the separation layer in the abscission zone helps determine the timing of petal drop is strongly supported by the finding that both physical (detachment force experiments) and anatomical investigations point in this direction. However, anatomical appearances do not tell us when the changes in enzymes have occurred that render the separation layer ready for destruction. The regression equation and results from the petal detachment forces can be used in screening sunflower cultivars for detachment force to determine groupings of short-lived vs. longlived cultivars. This result is also beneficial to breeding programs that are directed toward the improvement of sunflower longevity. Furthermore, this knowledge will lead to overall increase in sales of sunflowers by growers. Because petal drop in sunflowers is the result of the development of an abscission zone, future studies on exogenous chemical application, cold storage temperatures to slow down this development, and extend vase life of cut sunflowers should be carried out.

\section{Literature Cited}

Blacquière, T., N. Straver, and D. van den Berg. 2002. Possibilities for using photoperiodism to program flowering of sunflowers (Helianthus annuus) in the greenhouse and in the open. Acta Hort. 580:101109.

Devecchi, M. 2005. Postharvest physiology of cut flowers of sunflowers 'Sunrich Orange' (Helianthus annuus L.): First experimental results. Acta Hort. 669:381-388.
Evensen, K.B., A.M. Page, and A.D. Stead. 1993a. Anatomy of ethylene-induced petal abscission in Pelargonium $\times$ hortorum. Ann. Bot. (Lond.) 71:559-566.

Evensen, K.B., A.M. Page, and A.D. Stead. 1993b. Anatomy of ethylene-induced petal abscission in Pelargonium $\times$ hortorum. Ann. Bot. (Lond.) 71:650-656.

Facey, V. 1950. Abscission in leaves of Fraxinus americana L. New Phytol. 49:103-116.

Fernandez, D.E., G.R. Heck, S.E. Perry, S.E. Patterson, A.B. Bleecker, and S.-C. Fang. 2000. The embryo MADS domain factor AGL15 acts post-embryonically: Inhibition of perianth senescence and abscission via constitutive expression. Plant Cell 12:183-197.

Gawadi, A.G. and G.S. Avery. 1950. Leaf abscission and the so called abscission layer. Amer. J. Bot. 37:172-180.

Hodgson, R.W. 1918. An account of the mode of foliar abscission in Citrus. Univ. California. Publ. Bot. 6:417-428.

Johansen, D.A. 1940. Plant microtechnique. McGraw Hill, New York, NY.

Lease, K.A., S.K. Cho, and J.C. Walker. 2006. A petal break strength meter for Arabidopsis abscission studies. 4 June 2014. <http:// www.plantmethods.com/content/2/1/2>.

McKenzie, R.J. and P.H. Lovell. 1992. Perianth abscission in montbretia (Crocosmia $\times$ crocosmiiflora). Ann. Bot. (Lond.) 69:199-207.

Moebius-Clune, B.N., H.M. van Es, O.J. Idowu, R.R. Schindelbeck, D.J. Moebius-Clune, D.W. Wolfe, G.S. Abawi, J.E. Thiess, and B.K. Guginod. 2008. Long-term effects of harvesting maize stover and tillage on soil quality. Soil Sci. Soc. Amer. J. 72:960-969.

Osborne, D.J. 1989. Abscission. Critical Rev. Plant Sci. 8:103-129.

Patterson, S.E. and A.B. Bleecker. 2004. Ethylene-dependent and independent processes associated with floral organ abscission in arabidopsis. Plant Physiol. 134:194-203.

Polito, V.S. and S. Lavee. 1980. Anatomical and histochemical aspects of ethephon-induced lead abscission in olive (Olea europaea). Bot. Gaz. 141:413-417.

Ruzin, S.E. 1999. Plant microtechnique and microscopy. Oxford Univ. Press, New York, NY/Oxford, UK.

Sexton, R. 1994. Abscission, p. 497-525. In: Pessarrakli, M. (ed.). Handbook of plant and crop physiology. Marcel Dekker, New York, NY.

Sexton, R., G. Laird, and W. van Doorn. 2000. Lack of ethylene involvement in tulip tepal abscission. Physiol. Plant. 108:321-329.

Sexton, R., L.N. Lewis, A.J. Trewavas, and P. Kelly. 1985. Ethylene and abscission, p. 173-196. In: Roberts, J.A. and G.A. Tucker (eds.). Ethylene and plant development. Butterworths, London, UK.

Sexton, R. and A.J. Redshaw. 1981. The role of cell expansion in the abscission of Impatiens sultani leaves. Ann. Bot. (Lond.) 48:745757.

Sexton, R. and J.A. Roberts. 1982. Cell biology of abscission. Annu. Rev. Plant Physiol. 33:133-162.

Webster, B.D. 1973. Ultrastructural studies of abscission in Phaseolus: Ethylene effects on cell walls. Amer. J. Bot. 60:436-447. 